Alan J. Abramson*

\title{
Making Public Policy toward the Nonprofit Sector in the U.S.: How and Why Broad, "Sector" Interests Are Advanced - Or Not - in Federal Policymaking
}

DOI 10.1515/npf-2015-0050

Abstract: The nonprofit sector is a vital part of U.S. society with roots deep in the country's history. In light of the nonprofit sector's favored place in American society, it is perhaps not surprising that nonprofit leaders have had some important successes in advancing sector-interests in federal policymaking since 2000, which is the focus of this paper. Nonprofit sector advocates have secured some significant new sector-wide benefits (e. g., the recently established mandate that nonprofit contractors paid with federal funds be reimbursed reasonable indirect costs) and, perhaps just as importantly, have fended off numerous attacks on sector interests (e. g., efforts to cap the value of itemized deductions for upper-income taxpayers). However, while nonprofit sector leaders have won some notable policy victories in recent decades, especially in defending sector interests, they have also been somewhat frustrated in efforts to advance the sector even further by a variety of structural and other constraints that weaken the nonprofit sector (and some other industries) in federal policymaking. Importantly, almost all interests typically win many more "defensive" than "offensive" policy victories. At the same time, nonprofit sector advocates have also been weakened by free riders (who limit advocacy in other industries as well), the subsector orientation of many nonprofits, limits on nonprofit lobbying and electoral activity, the disconnect of national sector advocates from local nonprofit leaders, and other reasons. Suggestions for overcoming these challenges include: strengthening links between local and national sector advocates, connecting sector and subsector advocacy efforts, perhaps relaxing restrictions on nonprofit lobbying and electoral activity, better resourcing

*Corresponding author: Alan J. Abramson, School of Policy, Government, and International Affairs, George Mason University, 3351 Fairfax Drive, Room 608 - MS 3B1, Arlington, VA 22201, USA, E-mail: aabramso@gmu.edu 
national sector advocates, and finding and communicating the "big idea" behind the sector that will persuade policymakers to be more supportive.

Keywords: nonprofit policy, U.S., advocacy

\section{Introduction: A Puzzle}

Nonprofit activity is deeply rooted in U.S. history. Alexis de Tocqueville, a famous French visitor to the U.S. in the early 1800s, observed that Americans were constantly forming associations, or what we would now call nonprofit organizations, for a variety of social purposes (Tocqueville 1969, 513). Today, 180 years later, Americans still turn regularly to nonprofits to address a broad range of challenges: feeding the hungry, housing the homeless, caring for the sick, conducting research, showcasing music and art, and many other purposes.

In the context of Americans' longstanding reliance on and general affection for nonprofit organizations, it is perhaps not surprising that nonprofit leaders have had some important successes in advancing sector-wide interests in federal policymaking since 2000, which is the focus of this paper. Nonprofit sector advocates have secured some significant new sector-wide benefits (e. g., the recently established mandate that nonprofit contractors paid with federal funds be reimbursed reasonable indirect costs) and, perhaps just as importantly, have fended off numerous attacks on sector interests (e. g., efforts to cap the value of itemized deductions for upper-income taxpayers).

However, while nonprofit sector leaders have won some notable policy victories in recent decades, especially in defending sector interests, they have also been a bit frustrated in efforts to advance the sector even further by a variety of structural and other constraints that weaken the nonprofit sector in federal policymaking. This paper explores the puzzle - or paradox - of a nonprofit sector that is highly valued by U.S. citizens but that has had somewhat modest success in policymaking despite the best efforts of talented sector leaders.

To do so, the paper provides an overview of the relatively expansive U.S. nonprofit sector; cites evidence about the sector's popularity with Americans; discusses the sector's stake in the policy process; identifies the organizations that represent sector interests in national policymaking and examines their recent advocacy efforts; considers why the nonprofit sector has had rather modest policy success; and offers recommendations about how the sector might strengthen itself in federal policymaking.

To develop this paper, the author builds on the existing literature in the field, especially theory, empirical findings, and descriptive data on the size and 
scope of the nonprofit sector; the sector's public image; and reasons for the modest success of sector-wide advocacy efforts. To this foundation, the paper adds information and analyses based on two dozen interviews with a broad range of nonprofit and foundation leaders and other key informants that have been conducted over the past decade; scholarly and journalistic accounts of recent nonprofit policy activity; and a review of documents from relevant organizations, especially Independent Sector, which is the largest umbrella organization for the nonprofit sector at the federal level.

Throughout, the focus of the paper is on broad "sector" - or sector-wide issues rather than policy matters that affect nonprofits in only one or a few subsectors, like health, education, or human services. Thus, the interest here is in nonprofit regulatory, tax, and funding issues - like regulations related to nonprofit advocacy or tax provisions related to the deductibility of charitable contributions or government contracting procedures - that affect nonprofits across a broad range of subsectors. While subsector matters often seem to receive greater attention from many, individual nonprofits, the cross-cutting, sector-wide policy issues that relate to the basic ways that government treats these organizations also have significant impacts on the structure, revenues, and activities of nonprofit organizations and are the main focus here.

As mentioned above, the paper concentrates on nonprofit policy activities at the federal level, where many critical decisions are made, with less attention to developments at the state and local levels, which are also important but which could be the subject of an entirely different paper. Finally, as also noted above, the paper focuses on nonprofit policy activities in the years 2000-2015, overlapping somewhat with other recent analyses of nonprofit policy and also picking up where they left off (see, for example, Young 2010).

\section{Overview of U.S. Nonprofit Sector}

Before turning to examine nonprofit policy activity in some detail, we first define what the U.S. nonprofit is and describe its size and scope, drawing largely on data collected by the National Center for Charitable Statistics at the Urban Institute.

The nonprofit sector is one of three major formal sectors in society, along with the government and business sectors. ${ }^{1}$ The presumption is that all organizations can be sorted into one of the three sectors, although because of the blurring of the boundaries between the sectors there are some hybrid

1 Some would include "households" as another, informal sector of the economy. 
organizations that are hard to place in just one sector and seem to lie on a fuzzy border between two sectors. ${ }^{2}$

In 2010, the nonprofit sector comprised $5.5 \%$ of the U.S. gross domestic product (GDP), making it the smallest of the three sectors behind government, which was $12.5 \%$ of GDP, and business which was $74.9 \%$ of GDP (Roeger, Blackwood, and Pettijohn 2012, 10). ${ }^{3}$ By another measure, the nonprofit sector appears to be a somewhat larger portion of the economy, as it accounted for $9.0 \%$ of wage and salary accruals in 2010 , compared to $17.0 \%$ for government and $73.8 \%$ for business (Roeger, Blackwood, and Pettijohn 2012, 17).

The term "nonprofit sector" does not have a completely clear meaning in the U.S. Organizations can be exempt from taxation under more than 30 sections of the Internal Revenue Code, which is the U.S. federal tax code. In fiscal year 2014, the Internal Revenue Service (IRS), the U.S. federal tax agency, counted a total of 1.7 million tax-exempt organizations, nonexempt charitable trusts and split-interest trusts (Internal Revenue Service 2015b, 58). Of these, 1.1 million, or nearly two-thirds of the total, were tax-exempt under section 501(c)(3) of the tax code. These religious, charitable, and similar organizations are the main focus of this chapter. ${ }^{4}$

Organizations exempt under section 501(c)(3) of the tax code have the benefit of being able to offer their donors the opportunity to deduct their charitable contributions from their taxable income. Organizations that are exempt from federal taxation under section 501(c)(3) may also be exempt from state and local sales and property tax levies depending on state and local laws.

Organizations qualify for 501(c)(3) status by satisfying a five-part test spelled out in the relevant section of the tax code. In particular, organizations exempt from taxation under section 501(c)(3) are (Cornell University Law School 2015):

- Corporations, and any community chest, fund, or foundation,

- Organized and operated exclusively for religious, charitable, scientific, testing for public safety, literary, or educational purposes, or to foster national

2 For example, in recent years there has been significant commentary about the growth of hybrid, "double-bottom-line" organizations that aim both to do good, like nonprofits, and also make money, like for-profits (see, for example, Young, Salamon, and Grinsfelder 2012). As of August 2015, 31 states allow for "benefit corporations," which are required to consider the impact of their decisions not only on shareholders but also on workers, the community, and the environment (Benefit Corporation 2015). Some argue that with the proliferation of hybrids there is essentially a "Fourth Sector" which is emerging (Sabeti 2011).

3 Households comprised 7.1\% of GDP (Roeger, Blackwood, and Pettijohn 2012, 10).

4 Other major categories of tax-exempt organizations, which are of less concern in this paper, are: 501(c)(4) "social welfare organizations," which are close cousins of 501(c)(3) charitable organizations; 501(c)(5) labor unions and related organizations; 501(c)(6) business associations; and 501(c)(7) fraternal associations. 
or international amateur sports competition (but only if no part of its activities involve the provision of athletic facilities or equipment), or for the prevention of cruelty to children or animals;

- No part of the net earnings of which inures to the benefit of any private shareholder or individual,

- No substantial part of the activities of which is carrying on propaganda, or otherwise attempting, to influence legislation (except as otherwise provided in subsection (h)), and

- Which does not participate in, or intervene in (including the publishing or distributing of statements), any political campaign on behalf of (or in opposition to) any candidate for public office.

In simplified terms, 501(c)(3) nonprofits have some formal organizational structure; are engaged in one of a number of exempt activities; do not distribute their profits; do not spend a substantial amount of their resources on lobbying; and do not get involved in political campaigns in favor of one candidate or another. From here on, we use the term "nonprofits" to refer specifically to 501(c)(3) organizations.

Organizations complete IRS Form 1023 in order to have their 501(c)(3) status recognized by the IRS. An important exception is that religious organizations can self-declare their nonprofit status and do not have to seek approval from the IRS. Non-religious nonprofits are also required to file Form 990 information returns annually with the IRS reporting on their income and expenses. Organizations with annual gross income of $\$ 50,000$ or less are only required to file Form $990-\mathrm{N}$, also known as the e-Postcard, which asks for eight simple items of information (Internal Revenue Service 2015a).

As indicated above, the IRS's most recent statistics indicate there are a total of 1.1 million 501(c)(3) nonprofits in 2014, although this number does not include many religious congregations or small organizations with receipts of less than $\$ 5,000$ which are not required to register with the IRS. Financial statistics are available for "reporting public charities," which are the nearly 300,000 501(c)(3) nonprofits with more than $\$ 50,000$ in revenue that file 990 information forms. These organizations had expenses of $\$ 1.6$ trillion in 2013. By far, the largest portion of nonprofit expenses, $60 \%$ of the total, is attributable to health organizations, including large nonprofit hospitals and nursing homes. The second largest nonprofit subsector is education, which includes large nonprofit colleges and universities, and makes up $17 \%$ of total nonprofit expenses. Human services organizations account for $13 \%$ of expenses; arts organizations for 2\% of expenses, and other organizations $8 \%$ (McKeever 2015, 6).

It is a surprise to many, especially those who are not nonprofit researchers, what the largest sources of nonprofit revenue are. There are three major sources 
of nonprofit income: earned revenue, including income from fees for service; government payments, including funds received through grants and contracts with federal, state, and local governments; and philanthropy, including contributions from individuals, foundations, corporations, and bequests. Most guess that philanthropy is the largest source of nonprofit revenue. However, in 2013, earned revenue made up $48 \%$ of nonprofit revenue; government payments comprised $33 \%$ of income; and philanthropy accounted for "only" $13 \%$ of income (McKeever 2015, 5). Thus, business-type income from earned revenue as well as government payments provide more revenue to nonprofits, at least in the aggregate, than income from philanthropy, which is the funding source most closely associated with nonprofits.

Of course, this is a very aggregate - or big picture - portrayal of nonprofit sources. Below the aggregate, different types of nonprofits have different revenue profiles. At the subsector level, health and education nonprofits tend to be most dependent on fees, while human service organizations receive more payments from government, and religious and arts groups are more heavily financed by philanthropy (Roeger, Blackwood, and Pettijohn 2012, 175-199). And, of course, the revenue breakdown for any single nonprofit can take many different forms.

There are surprises as well in looking more closely at the sources of philanthropy. In 2014, total charitable giving from all sources amounted to $\$ 358$ billion. While many believe that corporations and perhaps foundations contribute the bulk of philanthropy, in fact individuals account for the largest portion of giving, $72 \%$. Foundations make up $15 \%$ of giving, bequests account for $8 \%$, and corporations make up $5 \%$. To be sure, a significant portion - roughly $45 \%$ - of individual giving goes to religion. But, even if religious giving is excluded from giving totals, individual giving would still make up the largest portion - almost $60 \%$ - of giving (Giving USA 2015).

Clearly, the nonprofit sector has a broad base of support - with revenue from a wide range of paying customers, government agencies buying nonprofit services, and donors - as well as contributions from millions of volunteers. In fact, the U.S. stands out relative to most other countries in terms of the size and importance of the nonprofit sector in the U.S. economy and society more broadly. According to the systematic analyses of the Comparative Nonprofit Sector Project at the Johns Hopkins University, the U.S. ranks quite high compared to many other countries in terms of volunteering and the percent of the workforce employed in "civil society" - or nonprofit - organizations as well as in the overall size, sustainability, and impact of these organizations (Salamon, Sokolowski, and Associates 2004). 


\title{
Public Affection for the Nonprofit Sector
}

In the U.S., the broad and deep financial support for the nonprofit sector is consistent with - and perhaps results from - the public's general affection for nonprofit organizations. As stated at the start, nonprofit activity is deeply rooted in American history. The French visitor Alexis de Tocqueville observed in Democracy in America $(1969,513)$, his magisterial, two-volume commentary on America in the 1800s:

\begin{abstract}
There are not only commercial and industrial associations in which all take part, but others of a thousand different types-religious, moral, serious, futile, very general and very limited, immensely large and very minute. Americans combine to give fetes, found seminaries, build churches, distribute books, and send missionaries to the antipodes. Hospitals, prisons, and schools take shape in that way. Finally, if they want to proclaim a truth or propagate some feeling by the encouragement of a great example, they form an association. In every case, at the head of any new undertaking, where in France you would find the government or in England some territorial magnate, in the United States you are sure to find an association.
\end{abstract}

Americans believe strongly in individualism and self-reliance. They prefer to rely on community organizations - nonprofits - to address needs that cannot be met through individual action, and turn to government only as a last resort. ${ }^{5}$

Almost two hundred years after Tocqueville wrote, surveys indicate that Americans still rely heavily on and feel fondly about the nonprofit sector. A 2013 Gallup opinion poll reported that $65 \%$ of Americans surveyed said they volunteered their time to a religious organization or some other charity in the past year, and $83 \%$ said they donated money (Gallup Editors 2013). Consistent with Americans' support of nonprofits, based on extensive polling data O'Neill $(2009,240)$ finds that Americans express relatively significant levels of trust and confidence in nonprofits, generally ranking them higher than government and business on these dimensions. In the latest available poll, a June 2015 survey conducted by Princeton Survey Research Associates International, almost two-thirds of Americans expressed "a great deal" or "a fair amount" of confidence in charities (Perry 2015, 10). While Light (2008) worries about a loss of public affection for nonprofits in recent decades, this decline may reflect what surveys find is a reduced faith in all kinds of institutions (e. g., see Jones 2015) rather than an isolated reduction in public support for nonprofits. And, in any case, even with some decline in confidence in nonprofits, support for these institutions remains quite high overall. However, an important question is why this significant public support of nonprofits has not translated into greater policy success in Washington, DC, the nation's capital.

5 On Americans’ longstanding preference for limited government, see Kingdon (1999). 


\section{The Nonprofit Sector's Significant Stake in Federal Policy Decisions}

Why, in fact, does Washington matter to nonprofits? What stake do nonprofits have in federal policymaking? ${ }^{6}$ Various federal tax, spending, and regulatory policies have important impacts on the size, shape, operation, and role of the nonprofit sector in the U.S. For example, federal tax policy determines the kinds of organizations that can claim tax-exempt status and the deductibility of charitable contributions to nonprofits. Marginal tax rates affect the "price of giving" and thus influence how much individuals donate (Abramson, Salamon, and Steuerle 2006, 121). As it turns out, when tax rates go up, the price of giving goes down - it costs taxpayers less to give to charity - and taxpayers have increased incentives to give to nonprofits. When tax rates go down, giving incentives decrease. Of course, currently only taxpayers who itemize their deductions are able to take advantage of a tax incentive to give, so tax provisions that affect the number of itemizers also impact the amount of giving. Over the past decade, nonprofits have been sometimes interested in debates concerning possible reduction of the estate tax and capital gains tax. Reducing these taxes would likely lead to an increase in the price of giving and a decline in charitable contributions. ${ }^{7}$

Like federal tax policy, federal spending impacts nonprofits in multiple ways. In the first place, the level of federal outlays affects the demand on nonprofits for services. For example, if federal spending for the Supplemental Nutrition Assistance Program (SNAP; formerly the Food Stamp program), declines, then more hungry people are likely to turn to nonprofit soup kitchens and other feeding programs for assistance. In addition to having a "demand" effect on nonprofits, federal spending may also have a "supply" effect since federal funding affects the supply of contract and grant funding for nonprofits and impacts their ability to provide services and meet demand. So, for example, federal payments to nonprofit organizations to provide Head Start programs has a significant impact on the balance sheets of these organizations and on their ability to meet client needs. As it turns out, a large portion of the federal payments for services that flows to nonprofits reaches them indirectly after

6 For a list of sector-wide public policy issues compiled by Independent Sector, see Independent Sector (2012b, 215-216).

7 Note that state and local tax policies, which are not the main focus of this paper, typically excuse nonprofits from sales and property taxes, although this varies somewhat by jurisdiction, and some jurisdictions have established voluntary arrangements for nonprofits to provide services or payments-in-lieu-of-taxes to government (SILOTS and PILOTS). On the tax treatment of nonprofits generally, see Brody and Cordes (2006), and Brody (2010). 
passing through state and local governments, which may add some of their ownsource funding to supplement the federal funding. As noted above, altogether government reimbursements and other payments account for roughly one-third of total nonprofit revenue, so clearly the nonprofit sector has a big stake in federal spending decisions (Abramson, Salamon, and Steuerle 2006).

Federal tax policies and spending programs are often accompanied by federal regulations. So, section 501(c)(3) of the tax code specifies how organizations qualify for status as a charitable nonprofit. As indicated above, section 501(c)(3) indicates that qualifying organizations cannot spend a substantial part of their funding on lobbying and cannot take sides in partisan political activities. Other important federal regulations affecting nonprofits prohibit them from using federal funding to lobby; govern nonprofits' contract and grant relationships with government; and give nonprofits preferential status in competing for certain federal funding. A special set of regulations applies specifically to private foundations, including a provision that requires of foundations an annual, minimum pay-out of $5 \%$ of their assets. Again, while our focus is on federal activity, state and local government are also important regulators of nonprofits, as, for example, in their oversight of nonprofit fundraising. There are also many regulations that affect one or more nonprofit subsectors rather than the nonprofit sector as a whole, which is the main subject of this paper.

\section{Nonprofits' Mixed Success in the Policy Process}

As noted at the start, nonprofit sector advocates have won many important defensive victories in recent decades and have also extended nonprofit benefits on several occasions as well. However, in light of nonprofits' iconic place in American society, both historically and today, and the sector's important stake in federal tax, spending, and regulatory policy, it is somewhat puzzling that the sector has been only modestly successful in enhancing its position through the policy process. This section describes the sector's policy activity; the following section discusses why the sector has had mixed success especially in winning new benefits in policymaking.

\section{Sector Advocates}

The nonprofit sector engages in policymaking on broad, sector-wide issues largely through specialized support, or "infrastructure," organizations that 
have developed and become more important entities over the last several decades (Abramson and McCarthy 2012). The most important of these sector advocates that lead the nonprofit sector's federal policy activities are:

- Independent Sector: This 500-plus member organization, with 40 staff and a budget of about $\$ 10$ million, has sector advocacy as one of its major purposes. It is generally perceived as the voice of big nonprofits and foundations, with many of its most important members large national associations of nonprofits (e.g., YMCA of the USA, Catholic Charities USA, Lutheran Social Services) and large foundations (e.g., Bill and Melinda Gates Foundation, Ford Foundation, David and Lucile Packard Foundation).

- National Council of Nonprofits: The National Council of Nonprofits, formerly the National Council of Nonprofit Associations, is an umbrella organization for the 35 state nonprofit associations of nonprofits that combined represent more than 25,000 nonprofits around the country. The primary policy focus of the National Council of Nonprofits is at the state and local levels, although it does some work at the federal level as well.

- United Way Worldwide represents 1,800 community-based United Way chapters in the U.S. and 40 other countries around the world.

- Council on Foundations: With 1,600 members and a budget of about $\$ 15$ million, the Council focuses specifically on advancing the interests of the nation's grantmakers. While the Council's membership includes only a small percentage of the nation's grantmakers, it includes foundations with a significant share of the total assets of U.S. foundations.

- Forum of Regional Associations of Grantmakers: The Forum brings together 33 state and regional associations of grantmakers.

\section{Policy Activities and Results, 2000-2015}

These support organizations and other agencies engaged in a broad range of advocacy activities at the federal level on behalf of sector-wide interests in recent years. Sector advocates developed policy proposals and principles; held advocacy trainings; organized policy-related task forces; formed coalitions; collaborated with the federal government on conferences; educated, briefed and lobbied federal officials; testified in Congress; and filed amicus briefs in court cases where nonprofit interests might be affected. 
These advocacy organizations undertook these activities on a great variety of issues, including:

- $\quad$ Restoring the ability of non-itemizers - the majority of taxpayers who do not itemize their tax deductions - to nevertheless receive a federal tax break for their charitable contributions. This provision had been in effect in the early 1980s;

- Protecting the advocacy rights of nonprofits, including the ability of nonprofits that receive federal grants to engage in nonpartisan election activity;

- Increasing funding for IRS regulators to weed out bad nonprofits that harm the reputation of other nonprofits;

- Securing tax breaks for individuals who donate their IRA pension funds to nonprofits;

- Ensuring anti-terrorism guidelines do not hinder legitimate contributions;

- Resisting the complete repeal or significant reduction of the estate tax because of a negative impact on charitable giving;

- $\quad$ Revising the IRS 990 information return for nonprofits and mandating electronic filing of these forms to foster greater transparency;

- Fighting federal budget cuts that would reduce government funding for programs in which nonprofits deliver services;

- Reforming government contracting procedures so nonprofits would get paid on time, receive appropriate indirect cost reimbursement, and face less red tape in applying for and reporting on their government funding;

- Insuring nonprofits were treated fairly in health care reform;

- Opposing a cap on the tax breaks available to wealthy taxpayers for their charitable contributions;

- $\quad$ Resisting a cut in the postal rate discount available to nonprofits;

- Increasing the deduction for the creation of conservation easements; and

- Establishing a new federal office to be a voice for the nonprofit sector within the federal government. ${ }^{8}$

Many of these advocacy efforts involved proactive attempts to advance the nonprofit sector in new ways, but perhaps just as many were defensive efforts to fend off intentional or incidental attacks on sector interests. In fact, in assessing results, it seems that sector advocates were as, or even more, successful at the latter - playing defense - than the former - proactively advancing sector interests.

8 For a review of sector advocacy activity over the past fifteen years, see the various annual reports of Independent Sector listed in the reference section. (Independent Sector 2001, 2002, 2003, 2004, 2005, 2006, 2007, 2008, 2009, 2010, 2011, 2012a, 2013, 2014, 2015a, 2015b). 
As far as defensive activities, perhaps most importantly Independent Sector led the effort to fend off attacks from the Senate Finance Committee and its chair Senator Charles Grassley in the early-mid 2000s. Senator Grassley held a series of antagonistic hearings that highlighted the unethical and even illegal activities of some nonprofits, and his committee circulated a white paper, "Staff Discussion Draft" of suggested reforms, including a required five-year review of organizations' tax-exempt status by the IRS, the inclusion of detailed annual performance goals in nonprofits' Form 990 filings, and a mandated size for nonprofit boards of between three and fifteen members (Senate Finance Committee 2004). But Independent Sector largely deflected Congressional action with its argument that the sector could regulate itself. Independent Sector convened the Panel on the Nonprofit Sector which produced several reports laying out best practices for organizational governance and accountability for nonprofits. ${ }^{9}$ Overall, IS and its allies were quite successful in "changing the conversation" and preventing hostile Congressional action against the nonprofit sector.

Since 2000, sector advocates have also stopped continuing efforts by some members of Congress to limit lobbying by nonprofits receiving federal payments (Stehle 2009); persuaded the IRS to withdraw, at least temporarily, regulations on the political activity of 501(c)(4) organizations that would have also likely constrained the nonpartisan, election-related work of 501(c)(3) nonprofits (Daniels 2013; Internal Revenue Service 2014); and convinced the IRS to pull back regulations that would have encouraged nonprofits to collect Social Security numbers of donors to substantiate their gifts (National Council of Nonprofits 2016b). Moreover, sector advocates have stopped - at least as of April 2016 - efforts to limit the charitable deductions available to high-income earners (Independent Sector 2016).

In addition to their important successes in playing defense and protecting sector interests from attack, sector advocates have also been able to secure several major, new benefits for the nonprofit sector. The National Council of Nonprofits and its network led the effort to persuade OMB to include provisions favorable to nonprofits in its Uniform Guidance on federal grants management

9 See, for example, the reports by the Panel on the Nonprofit Sector and Independent Sector, "Strengthening Transparency, Governance, and Accountability of Charitable Organizations: A Final Report to Congress and the Nonprofit Sector" (2005); "Strengthening Transparency, Governance, and Accountability of Charitable Organizations: A Supplement to the Final Report to Congress and the Nonprofit Sector" (2006); and "Principles for Good Governance and Ethical Practice: A Guide for Charities and Foundations" (2007 and 2015). These reports can be retrieved from: https://www.independentsector.org/publications. The last report is available for a fee. 
which was issued in December 2014. Under the new rules, federal, state, and local governments must pay nonprofits at least $10 \%$ of their (modified total) direct costs to cover nonprofits' indirect - or overhead and administrative expenses when the work is funded in whole or in part by federal funds. And nonprofits can negotiate to receive even higher indirect rates from government (Delaney 2015).

Another major victory for sector advocates was the Pension Protection Act of 2006 which expanded tax incentives by: allowing individuals age 70 1/2 and above to donate up to $\$ 100,000$ from their Individual Retirement Accounts (IRAs) without having the contributions count as taxable income; extending the deduction for donations of food to all businesses; and increasing the deduction for contributions of property for conservation. While initially the tax incentives had to be renewed annually to remain in effect, in 2015 sector advocates persuaded legislators to make the tax breaks permanent, which was an important achievement.

Another recent policy victory was the passage of the Serve America Act in 2009, which expanded national service programs, established a Social Innovation Fund to assist nonprofits in scaling up, and authorized modest funding through the Corporation for National and Community Service to improve the organizational capacity of nonprofits. Other successes won by Independent Sector, the National Council of Nonprofits, and other sector advocates included the establishment of a short-lived Strengthening Communities Fund in the U.S. Department of Health and Human Services that also supported nonprofit capacity building; and inclusion of nonprofits in a small employer tax credit that was established in health care reform legislation to encourage small employers to extend health insurance to their employees.

\section{Explaining the Nonprofit Sector's Modest Record in Federal Policymaking}

Clearly, sector leaders have won some impressive defensive and proactive policy victories in recent decades. However, their efforts to advance sector interests even further have been constrained by a range of factors. Why has this important and popular nonprofit sector fared only modestly in extending broad, sector interests in federal policymaking? Previous studies of advocacy and the research conducted for this paper suggest a variety of possible explanations for the sector's modest policy success. Note that most of the explanations discussed below relate to structural handicaps that constrain all types 
of advocacy or that specifically limit nonprofit advocacy or advocacy that advances broad sector interests. Importantly, there was little evidence that failures of leadership in nonprofit support organizations were the reason for the sector's modest policy record. In fact, there was significant praise for the skills of many sector advocates.

Explanations for the nonprofit sector's limited success in advancing sector interests fall into three broad, somewhat overlapping categories: the modest success that all advocates, not just nonprofit sector advocates, achieve in policymaking; the limited investment in sector advocates and sector advocacy; and the modest political influence of the overall nonprofit sector and sector advocates.

\section{Modest Success of All Policy Advocates}

At the start, it is important to point out that nonprofit advocates are similar to advocates for many other causes in their focus on playing defense and protecting existing benefits, and in their limited success in winning new benefits. As Baumgartner and his colleagues $(2009,7)$ note in their important study of interest group lobbying, "The most common single goal across [the groups involved in the nearly 100 issues we examined] ... is, not surprisingly, to protect the status quo from a proposed change." And, as the researchers go on to emphasize, "the status quo tends to prevail" (236). So, nonprofit sector advocates have good company in focusing their efforts on protecting existing benefits and in being successful in doing so.

Similarly, in their modest success in securing new benefits, nonprofit advocates are also not alone. As Baumgartner and his colleagues $(2009,6)$ observe, "For the majority of our issues, little happened." Thus, it is not exceptional that few new laws were passed or few new regulations were written that benefit nonprofits since 2000. Of course, the polarized, partisan climate in Washington, DC in recent years seems to have slowed policymaking even further, and so the lack of major policy advances for the nonprofit sector (or any other industry) should not be surprising.

Defensive lobbying is often successful for nonprofit - or other industry advocates because it seems easier to activate and unite supporters to defend existing benefits. In contrast, it may be harder to unite nonprofit advocates to win new benefits because of their often somewhat divergent interests, and any opponents from outside the sector are also likely to mobilize more vigorously against granting new benefits to nonprofits. Thus, the bias toward the status quo. 
Even during the Obama presidency, with an executive who had worked in nonprofits, sat on foundation boards, and seemed to put a high personal value on volunteering, sector advocates managed only modest enhancements in public policy toward the sector (Perry 2012). As noted above, during the Obama years federal service programs were expanded, the 2009 Recovery Act provided increased federal funding for services provided by nonprofits, OMB issued its favorable Uniform Guidance, and advantageous tax provisions from the Pension Protection Act were made permanent. At the same time, sector advocates also had to fend off Obama administration proposals to cap the charitable tax deductions of the wealthy. Overall, and consistent with the findings in Baumgartner et al. (2009), there seemed to be only modest change in policy toward the nonprofit sector during the Obama presidency, at least through spring 2016.

\section{Modest Investment in Sector Advocates and Sector Advocacy}

Sector advocacy is also constrained because, for a variety of reasons (some of which also apply to other industries), the nonprofit sector devotes only modest resources to broad sector advocacy:

\section{Free Riders}

Mancur Olson's classic, 1965 treatise, The Logic of Collective Action, warns about the challenges of providing collective goods that can be enjoyed by individuals whether or not they contribute to the costs of providing the collective benefits. Abramson and McCarthy (2012) apply Olson's framework to nonprofit infrastructure organizations, including sector advocates, that support all nonprofits. Thus, the 1.1 million charitable nonprofits in the U.S. typically underinvest in advocacy concerning their collective interests. This occurs because of the ability of individual organizations - single nonprofits in this case - to "free ride" on the advocacy efforts supported by others. Thus, sector advocates, like Independent Sector, have difficulty getting individual nonprofits to pay membership dues to support Independent Sector's advocacy activities because the nonprofits will be able to enjoy the benefits of this advocacy whether or not they pay their dues. The result is limited resources to support collective advocacy and less advocacy effort than would occur if this collective action challenge did not exist. 


\section{Subsector Orientation of Many Nonprofits}

Abramson and McCarthy (2012, 426) also highlight the subsector orientation of many nonprofits as another obstacle slowing the formation and work of sectorwide, infrastructure organizations. Thus, nonprofits underinvest in advocacy on sector-wide issues because they typically see themselves first as part of a particular subsector - museums, youth development, nursing home care, higher education, environment, etc. - and only a distant second as belonging to the nonprofit sector as a whole. Moreover, subsector support organizations umbrella associations in the various nonprofit subfields - take care of many of the advocacy needs of nonprofits, often it seems more successfully than national sector advocates. Thus, the national advocates are typically runner-ups to subsector advocates for nonprofits considering who can best represent them in Washington and where they should allocate the scarce resources they have available for paying membership dues.

\section{Lack of Nonprofit Appreciation and Funder Support for Advocacy, Including Sector Advocacy}

Sector advocates suffer because of the lack of support from nonprofits and their funders for all kinds of advocacy, not just sector-wide advocacy. While some nonprofits specialize in advocacy and certainly understand its value, many others are focused on service delivery and are reluctant to invest significant resources in advocacy (Bass, Abramson, and Dewey 2014, 263). Many nonprofit executives rise in their organizations because of their program-related skills, whether in human services, arts, health, education, or other fields, and do not have advocacy experience. Moreover, nonprofit leaders typically prefer to spend scarce organizational resources on additional service delivery, which generally has a clear benefit for clients, rather than on advocacy with its more ambiguous and sometimes only long-term payoff. Thus, nonprofits often lack staff expertise in advocacy, do not want to invest in increasing their own capacity for advocacy, and are reluctant to support advocacy by sector advocates, even though the latter are likely to have skilled lobbyists on staff.

Moreover, nonprofits delivering services in communities may fail to support sector advocates operating at the federal level because the former do not understand the relevance of federal policy decisions. One challenge, for example, is the lack of visibility of federal funding streams to nonprofits on the ground in local communities. Government payments that local nonprofits receive for providing services often come from state and local governments, but frequently 
these lower levels of government are passing through significant federal funding. In the past, the federal role in funding was essentially hidden from many nonprofits who therefore did not understand the importance of tracking and trying to influence federal decisions. As a result, local nonprofits were further reluctant to invest in federal-level sector advocates. This may change with the mandate in the OMB Uniform Guidance that entities passing through federal funding must now disclose that fact.

Similarly, some foundations and other funders may be reluctant to fund advocacy, including sector advocacy. Legal prohibitions against foundations earmarking their grants for lobbying may scare off some foundations from supporting nonprofit advocacy even though foundations have significant latitude to do so (Alliance for Justice 2016; Proscio 2005).

\section{Other Constraints on Sector Advocates}

The major sector advocacy organizations are membership organizations. Before the advocates can take stands and do their advocacy work, they must get some level of agreement among their members on what they should advocate for. With the great diversity in the nonprofit sector, getting this agreement can be very difficult. Boards and staff may differ; nonprofits in different fields may have different views; both progressives and conservatives inhabit the nonprofit sector and this may lead to differences on sector issues. There are also different levels of tolerance for risk-taking among nonprofit leaders, leading some to be concerned about possible negative consequences of launching pro-active advocacy campaigns (e.g., the possibility that advocates will lose control of legislation they are pushing and have hostile provisions attached to the bills), and others much more willing to move ahead.

Sector advocates and their supporters may be especially reluctant to take stands that antagonize government policymakers since many nonprofits depend heavily on government for funds. Sector advocates and their partners may hold back from advocating and lobbying on their own behalf, even to the extent they are able, because they worry that angry policymakers will take revenge by cutting their support.

Finally, in this era when many advocacy groups are criticized for representing narrow, selfish interests, some sector supporters are reluctant to appear to be just one more special interest. The underlying argument is that the nonprofit sector has more to gain by being above the fray and not engaging in selfinterested advocacy, and benefiting from the public's support for a sector perceived to be operating in the broad public interest. 


\section{Modest Political Influence of the Overall Nonprofit Sector and Sector Advocates}

A third set of explanations for the nonprofit sector limited success in the federal policy process is the modest political influence of the overall nonprofit sector and sector advocates:

\section{Limits on Nonprofit Lobbying and Electoral Activity}

In the first place, the advancement of broad, nonprofit interests in the policy process is handicapped by legal limits on nonprofits' lobbying and partisan political activities. As noted above, according to section 501(c)(3) of the tax code which specifies the requirements organizations must meet to maintain tax-exempt status, nonprofits - including support organizations (specifically only those organized as 501(c)(3) charitable nonprofits) and other nonprofits cannot spend a significant portion of their resources on lobbying - here defined as contact with legislators around specific legislation - and cannot endorse or support, financially or otherwise, one political candidate over another. Sector advocates (and other nonprofits) can organize neutral candidate fora and provide factual information sheets on candidates. Nonprofits and foundations also enjoy a "self-defense exception," which removes the barriers on lobbying on issues that might affect the existence of an organization or its powers and duties (Hopkins 2009, 195-196).

To make things more complicated for sector advocates, they and other nonprofits can choose whether to abide by the "substantial part test" about how much they can lobby (i.e., lobbying cannot be a vaguely-defined, "substantial part" of what they do), or to fall under an "expenditure test," which clearly specifies how much they can spend on lobbying.

Overall, the broad consequences of the legal limitations on nonprofit lobbying and electoral activity are that sector advocates operate in the policy process essentially with one hand tied behind their backs. Innovative nonprofit leader Robert Egger sought to raise funds for candidates supportive of the nonprofit sector by establishing a 501(c)(4), nonprofit political action committee, CForward. However, the organization raised little money and thus had very modest funding to donate to its favored candidates.

A related handicap is that pro-sector voters do not make up an identifiable voting bloc that would attract candidate attention and support. That is, there is no obvious reward of more votes for candidates who pledge to support sector 
interests. Because of the restrictions on nonprofit electoral activity, 501(c)(3) nonprofits that are active in the voting arena must stick to nonpartisan activity. Nonprofit VOTE is an organization that encourages nonprofits to help their clients vote. However, reflecting limits on nonprofits' electoral activity that could be considered partisan, the organization's efforts are focused on encouraging increased overall voter participation rather than support for one candidate or another (Nonprofit VOTE 2015). In summer 2015, Nonprofit VOTE joined with Independent Sector, the National Council on Nonprofits, and United Way Worldwide in a new "Nonprofit Votes Count" campaign to encourage nonprofit staff, board members, and volunteers to register and vote. It will be interesting to watch whether this nascent effort develops a voting bloc that supports sector interests (Stiffman 2015).

\section{Lack of Visibility of Nonprofit Sector to Federal Policymakers}

While federal policymakers recognize the important role of some well-known nonprofits, such as the Red Cross, the Salvation Army, and the United Way, they do not have a deep understanding of the nonprofit sector as a whole and so may fail to support efforts by sector advocates to strengthen the sector. As discussed further in the next section, while the scope and important role of the business sector is clear to policymakers, the nonprofit sector is not similarly understood to be a critical part of American society whose broad sector interests must be protected and even advanced, even though nonprofit activity is valued and many individual nonprofits are held in high esteem.

Members of Congress and other federal policymakers may also overlook sector interests because they do not hear strong calls from local community leaders asking for their support of these interests. Local leaders who could be helpful in contacting their representatives in Washington on sector-wide issues seem generally weakly connected to federal-level sector advocates, especially Independent Sector. Independent Sector must work indirectly through its members that have local affiliates, like the YMCA or Catholic Charities, to motivate nonprofit leaders in communities to call on their members of Congress. In particular, Independent Sector and many of its members seem not well-structured to lobby members of the U.S. Senate who have state-wide constituencies. On the other hand, the National Council of Nonprofits has state affiliates that can assist in sector advocacy, but the national office and many of its member state associations are relatively small, sometimes fragile operations that have limited capacity to undertake significant federal lobbying initiatives, even though the network has many skilled advocates. 
Also contributing to the sector's lack of visibility and clout is its relatively modest size, roughly 5-10\% of GDP. Again, compared to the business sector, which comprises $75 \%$ of GDP, the nonprofit sector is important but obviously much smaller, and so does not command the same level of attention and deference from policymakers. As noted Yale political economist Charles Lindblom famously observed, the business sector holds a "privileged position" in American society, and, as became especially apparent during the Great Recession, some large businesses are seen as too big to let fail, even in the free-market system that holds sway in the U.S. (Lindblom 1977, 170-188). While the loss of nonprofits might, in fact, be very disruptive to many Americans, the nonprofit sector is not seen as vital to a well-functioning society as the business sector.

\section{Absence of a Compelling Vision for the Overall Nonprofit Sector}

Relatedly, while policymakers and Americans generally are drawn to the market and the business sector because of their ability to help people get ahead, their wealth-creating capacity, their efficiency, and their respect for freedom of choice, there is not a similarly compelling and universally-agreed-upon rationale for the nonprofit sector. While most Americans have affection for nonprofit “do-gooders," there are nagging doubts about nonprofits' efficiency, effectiveness, and ethics. More generally, it is not entirely clear what the "value-added" is of the sector; that is, what nonprofits contribute to society that is not also provided by business or government (Abramson and McCarthy 2012, 447). All in all, there is not a completely convincing "big idea" motivating strong support for the nonprofit sector.

\section{What to Do?}

For nonprofit leaders seeking to advance broad sector interests through stronger sector advocacy and a more proactive policy agenda, what can be done? Following are some options for sector leaders to consider. Note that these options are offered largely in the spirit of recommendations for sector advocates and others specifically interested in improving the condition of the nonprofit sector. However, the discussion in these pages does not address in any detail the question of whether a stronger and perhaps larger nonprofit sector are necessarily better for our society. 
For example, some - perhaps on the progressive side - may worry that increasing the sector's influence and enabling sector advocates to win larger deductions for charitable contributions would reduce government revenues and force cuts in government programs. For those who prefer more government rather than more nonprofit activity, this would be a negative result.

As another example, some others - perhaps on the conservative side - may object if sector advocates leverage greater power to convince policymakers to establish a government office on the nonprofit sector that the critics believe will needlessly enlarge government and unnecessarily regulate nonprofits.

Weighing the pro's and con's of any particular policy affecting nonprofits is obviously important but is not the main subject of this paper. Again, the following recommendations assume an interest in strengthening nonprofit sector advocates and the nonprofit sector, and describe some potential strategies for accomplishing these goals.

\section{Expand Sector's Advocacy Capacity}

As discussed above, because of the free-rider, collective-action problem and other factors, national sector advocates are under-resourced. Nonprofits shy away from paying for collective advocacy efforts when they can enjoy the benefits of these initiatives whether they help fund them or not. Foundations and large nonprofits offset some of the free-riding by small and medium-sized groups by paying more than their fair share of the costs of sector advocacy. But foundations may need to do even more. And individual nonprofits need additional encouragement to understand the stake they have in broad, sector-wide issues and to pay their membership dues and join associations, like Independent Sector and the National Council of Nonprofits, that advocate on their behalf.

Sector advocates should also look for more ways to bring subsector advocates together to advance broad sector interests. For example, while subsector advocates will have their own concerns to advance in federal budget politics, they could also be part of an expansive nonprofit coalition that lobbies around a broad "nonprofit" - or social - budget with more funding for programs of interest to the subsectors. Unfortunately, while there is an overall "defense budget" that draws the attention of diverse defense lobbyists, there is currently not a similar "nonprofit budget" that sector and subsector advocates unite to lobby for. Sector advocates must be creative in packaging broad sector issues in ways that capture the support of diverse subsector advocates, perhaps by using frameworks like a "nonprofit budget." 
More fundamentally, of course, sector advocates should have a policy agenda, including both defensive and proactive policy goals, that individual nonprofits can rally around. Few proactive policies are likely to receive unanimous support within the nonprofit, but some sector advocates have put forward significant policy plans. For example, the National Council of Nonprofits' (2016a) current policy agenda has a broad range of defensive and proactive goals, including enhanced incentives for giving and volunteering, increased funding for nonprofit capacity building, contracting reform, higher financial thresholds for nonprofit lobbying activities, job creation incentives that apply to nonprofits as employers, and increased federal data that identifies nonprofits' economic and employment impact.

\section{Increase Visibility of Sector}

Another approach to empowering sector advocates is to expand initiatives to educate federal policymakers about the nonprofit sector and to raise the sector's visibility for this important audience. Admittedly, marketing the broad nonprofit sector is challenging and may require a long-term effort, but successful projects could help increase the nonprofit sector's visibility and standing. For example, more than one sector leader has suggested running a public service advertisement about a "day without nonprofits," that asks its audience to imagine the tragic consequences if all nonprofits were to close their doors. It seems like a good idea to try more creative initiatives like this.

\section{Better Connect the Federal to the Local}

Sector advocacy would also be strengthened by better connecting local nonprofit leaders, who can call on their Washington representatives, to federal sector advocacy efforts. That is, it would be empowering for federal sector advocates if they could more easily enlist the help of local and state-level nonprofit staff and board members who have sway with federal policymakers. To be sure, federal sector leaders can call on local and state nonprofit leaders now, but there is somewhat of an institutional disconnect, with Independent Sector comprised largely of national organizations (some of which have local affiliates that are helpful in federal lobbying) and the National Council of Nonprofits representing state and regional groupings of nonprofits. While Independent Sector and the National Council of Nonprofits have collaborated informally in recent decades, it likely would strengthen sector advocacy for there to be 
stronger links between the two organizations and between federal, state, and local nonprofit leaders and advocates more generally.

\section{Sector Advocates that Seek to Advance Broad Sector Interests Should Also Engage on Select Subsector Issues}

Sector advocates, like Independent Sector, that work to advance broad sector interests have generally been leery of also advocating on subsector issues. However, this reluctance helps make subsector advocates similarly unenthusiastic about supporting Independent Sector's advocacy on broad sector interests. Sector advocates may benefit by becoming somewhat more involved on subsector issues, such as affordable housing, youth development, or mental health services, and thereby gain support from subsector advocates on broad sector causes.

\section{Ease Restrictions on Nonprofit Lobbying and Electoral Activity}

Like the other recommendations, this one needs more evaluation and discussion but should be seriously considered. Nonprofits are currently significantly constrained in their policy activity by rules that limit their lobbying and largely forbid their electoral activity. Unleashing nonprofits and sector advocates by easing these constraints would allow them to give stronger voice to their interests. It would also help if foundations were allowed to directly support nonprofit lobbying.

At the same time, permitting nonprofits to engage more fully in lobbying and partisan politics would also subject them and their advocates more directly to the negative aspects of political and policy engagement - such as being subject to shakedowns for political contributions - and so this option needs further exploration to determine whether it is a net plus or minus for the sector.

\section{Encourage Sector Advocates to Make More Use of Currently Available Opportunities to Lobby and Engage in Partisan, Election-Related Activities}

While 501(c)(3) nonprofits are prohibited from contributing to sympathetic political candidates and extensive lobbying, 501(c)(4) organizations have more freedom to 
engage in these activities. Some nonprofits, like the American Cancer Society and Sierra Club, have established affiliated 501(c)(4) organizations that undertake more lobbying and electoral activity than their 501(c)(3) arms. 501(c)(3), sector-wide advocacy organizations might explore whether creating new 501(c)(4) entities focused on sector-wide advocacy - or allying with some existing 501(c)(4) nonprofits - would increase their influence.

\section{Conclusion}

The nonprofit sector is a vital part of U.S. society with roots deep in the country's history. Americans feel positively about the nonprofit sector, and many work or volunteer in nonprofits or contribute financially to them. With skilled leaders leveraging the sector's popularity, in recent decades the nonprofit sector has successfully defended itself against many of the attacks on its interests and has also won several policy victories that have improved its position.

However, especially in terms of proactive policy achievements that enhance the nonprofit sector's standing, it seems that, overall, the sector has had only relatively modest success in the policy arena. Of course, as Baumgartner and his colleagues (2009) find, almost all interests typically win many more "defensive" than "offensive" policy victories. As far as the nonprofit sector, sector advocates at the federal level, like Independent Sector, the National Council of Nonprofits, and others, remain weakened by free riders, the subsector orientation of many nonprofits, limits on nonprofit lobbying and electoral activity, the disconnect of federal sector advocates from local nonprofit leaders, and other reasons.

Suggestions for overcoming these challenges include strengthening links between local and federal sector advocates, connecting sector and subsector advocacy efforts, perhaps relaxing restrictions on nonprofit lobbying and electoral activity, better resourcing federal sector advocates, and finding and communicating the "big idea" behind the sector that will persuade policymakers to be more supportive. Some of these suggestions can be tried in the near-term but strengthening broad sector interests in federal policymaking is apt to be a long-term effort.

Acknowledgments: The author gratefully acknowledges helpful suggestions from several readers, including three anonymous reviewers, as well as the research help of Shelley Bradley, Emily Connelly, and Emily Fay. 
Funding: The Charles Stewart Mott Foundation is a major sponsor of Nonprofit Policy Forum, underwriting its open access to the public. Other sponsors include the Levin College at Cleveland State University and the Association for Research on Nonprofit Organizations and Voluntary Action. This special issue was funded through a grant by the Kresge Foundation to ARNOVA.

\section{References}

Abramson, A. J., and R. McCarthy. 2012. "Infrastructure Organizations." In The State of Nonprofit America, 2nd ed., edited by L. M. Salamon, 423-58. Washington, DC: Brookings Institution Press.

Abramson, A. J., L. M. Salamon, and C. E. Steuerle. 2006. "Federal Spending and Tax Policies: Their Implications for the Nonprofit Sector." In Nonprofits and Government: Collaboration and Conflict, 2nd ed., edited by E. T. Boris and C. E. Steuerle, 107-40. Washington, DC: Urban Institute Press.

Alliance for Justice. 2016. "Resources for Foundations Funding and Supporting Advocacy." Bolder Advocacy. An Initiative of Alliance for Justice. http://bolderadvocacy.org/focus-onfoundations/resources-for-foundations-funding-and-supporting-advocacy.

Bass, G. D., A. J. Abramson, and E. Dewey. 2014. "Effective Advocacy: Lessons for Nonprofit Leaders from Research and Practice." In Nonprofits and Advocacy: Engaging Community and Government in an Era of Retrenchment, edited by R. J. Pekkanen, S. R. Smith, and Y. Tsujinaka, 254-93. Baltimore, MD: Johns Hopkins University Press.

Baumgartner, F. R., J. M. Berry, M. Hojnacki, D. C. Kimball, and B. L. Leech. 2009. Lobbying and Policy Change: Who Wins, Who Loses, and Why. Chicago: University of Chicago Press.

Benefit Corporation. 2015. "State by State Status of Legislation.” Accessed August 11. http://benefitcorp.net/

Brody, E. 2010. "All Charities Are Property-Tax Exempt, but Some Charities Are More Exempt Than Others." New England Law Review 44:621-732.

Brody, E., and J. J. Cordes. 2006. "Tax Treatment of Nonprofit Organizations: A Two-Edged Sword?" In Nonprofits and Government: Collaboration and Conflict, 2nd ed., edited by E. T. Boris and C. E. Steuerle, 141-80. Washington, DC: Urban Institute Press.

Cornell University Law School. 2015. "26 U.S. Code Sec. 501 - Exemption From Tax on Corporations, Certain Trusts, Etc.” Accessed August 11. https://www.law.cornell.edu/ uscode/text/26/501.

Daniels, A. 2013. "Nonprofits Say New Proposed IRS Rules Would Hamper Their Advocacy Efforts." Chronicle of Philanthropy. Accessed December 5, 2013. https://philanthropy. com/article/Nonprofits-Say-New-Proposed/153955.

Delaney, T. 2015. "Nonprofits Win Key Victory in Overhead Battles With Government." Chronicle of Philanthropy, Accessed January 13. https://philanthropy.com/article/OpinionNonprofits-Win-Key/151979.

Gallup Editors. 2013. "Most Americans Practice Charitable Giving, Volunteerism." Gallup Well-Being, Accessed August 10. http://www.gallup.com/poll/166250/americanspractice-charitable-giving-volunteerism.aspx. 
Giving USA. 2015. Living USA 2015 Highlights. Indianapolis, IN: Lilly Family School of Philanthropy, Indiana University. Accessed August 12. http://givingusa.org/.

Hopkins, B. R. 2009. Starting and Managing a Nonprofit Organization: A Legal Guide, 5th ed. Hoboken, NJ: John Wiley and Sons.

Independent Sector. 2001. 2000 Annual Report: Shaping the Future of the Sector. https://www.independentsector.org/uploads/About_IS/Key_Documents/2000_Annual_ Report.pdf.

Independent Sector. 2002. 2001 Annual Report: Leading the Charge. https://www.indepen dentsector.org/uploads/About_IS/Key_Documents/2001_Annual_Report.pdf.

Independent Sector. 2003. 2002 Annual Report: Leadership for a New Future. https://www. independentsector.org/uploads/About_IS/Key_Documents/2002_Annual_Report.pdf.

Independent Sector. 2004. 2003 Annual Report: Building Together. https://www.independent sector.org/uploads/About_IS/Key_Documents/2003_Annual_Report.pdf.

Independent Sector. 2005. 2004 Annual Report: Listening, Leading Mobilizing. https://www. independentsector.org/uploads/About_IS/Key_Documents/2004_Annual_Report.pdf.

Independent Sector. 2006. 2005 Annual Report: Strengthening Democracy, Building A More

Effective, More Accountable Charitable Sector. https://www.independentsector.org/ uploads/About_IS/Key_Documents/2005_Annual_Report.pdf.

Independent Sector. 2007. 2006 Annual Report: Many Voices, Shared Purpose, Working Together To Improve Lives. https://www.independentsector.org/uploads/About_IS/Key_ Documents/2006_Annual_Report.pdf.

Independent Sector. 2008. 2007 Annual Report: Opportunity and Responsibility. https://www. independentsector.org/uploads/About_IS/Key_Documents/2007_Annual_Report.pdf.

Independent Sector. 2009. 2008 Annual Report: Our Hopes, Our Voice, Our Future. https://www. independentsector.org/uploads/About_IS/Key_Documents/2008_Annual_Report.pdf.

Independent Sector. 2010. 2009 Annual Report: Challenging Times, New Opportunities. https:// www.independentsector.org/uploads/About_IS/Key_Documents /2009_Annual_Report.pdf.

Independent Sector. 2011. 2010 Annual Report: Forging A Stronger Future, Together. https:// www.independentsector.org/uploads/About_IS/Key_Documents/2010_AnnualReport-v10Final.pdf.

Independent Sector. 2012a. 2011 Annual Report: R-evolutionary Times. http://independentsec tor.org/uploads/About_IS/Key_Documents/2011AnnualReport.df.

Independent Sector. 2012b. Beyond the Cause: The Art and Science of Advocacy. Washington DC: Independent Sector.

Independent Sector. 2013. 2012 Annual Report: Game Changers. https://www.independentsec tor.org/uploads/About_IS/2012AnnualReport.pdf.

Independent Sector. 2014. 2013 Annual Report: Lead On. https://www.independentsector.org/ uploads/About_IS/2013AnnualReport.pdf.

Independent Sector. 2015a. 2014/2015 Annual Report: Join Us on Our Journey. http://annual report.independentsector.org/.

Independent Sector. 2015b. Principles for Good Governance and Ethical Practice. Accessed August 26, 2015. https://www.independentsector.org/uploads/PrincipleResources/The _ 33_Principles.pdf.

Independent Sector. 2016. "The Charitable Deduction.” Accessed April 3. https:// www.independentsector.org/charitable_deduction. 
Internal Revenue Service. 2014. "IRS Update on the Proposed New Regulations on 501(c)(4) Organizations." Accessed April 3, 2016. https://www.irs.gov/uac/Newsroom/IRS-Updateon-the-Proposed-New-Regulation-on-501(c)(4)-Organizations.

Internal Revenue Service. 2015a. "Annual Electronic Filing Requirement for Small Exempt Organizations - Form 990-n (e-Postcard).” Accessed August 11. http://www.irs.gov/ Charities-\&-Non-Profits/Annual-Electronic-Filing-Requirement-for-Small-ExemptOrganizations-Form-990-N-(e-Postcard).

Internal Revenue Service. 2015b. Internal Revenue Service Data Book, 2014. Publication 55B. Washington, DC. Accessed August 11. http://www.irs.gov/pub/irs-soi/14databk.pdf.

Jones, J. M. 2015. “Confidence in U.S. Institutions Still Below Historical Norms.” Gallup. June 15, 2015. Accessed October 30. http://www.gallup.com/poll/183593/confidenceinstitutions-below-historical-norms.aspx.

Kingdon, J. W. 1999. America the Unusual. Boston, MA: Wadsworth.

Light, P. C. 2008. How Americans View Charities: A Report on Charitable Confidence, 2008. Issues in Governance Studies. Washington, DC: Brookings Institution.

Lindblom, C. E. 1977. Politics and Markets: The World's Political-Economic Systems. New York: Basic Books.

McKeever, B. S. 2015. The Nonprofit Sector in Brief 2015: Public Charities, Giving, and Volunteering. Washington, DC: Urban Institute. http://www.urban.org/sites/default/files/ alfresco/publication-pdfs/2000497-The-Nonprofit-Sector-in-Brief-2015-Public-CharitiesGiving-and-Volunteering.pdf.

National Council of Nonprofits. 2016a. "2016 Public Policy Agenda." Accessed April 3. https:// www.councilofnon profits.org/sites/default/files/documents/2016-public-policy-agenda.pdf.

National Council of Nonprofits. 2016b. "Gift Substantiation Proposed Regulation.” Accessed April 3. https://www.councilofnonprofits.org/trends-policy-issues/gift-substantiationproposed-regulations.

Nonprofit VOTE. "Our Mission.” Accessed August 18. http://www.nonprofitvote.org/ourmission/

Olson, M. 1965. The Logic of Collective Action: Public Goods and the Theory of Groups. Cambridge, MA: Harvard University Press.

O'Neill, M. 2009. "Public Confidence in Charitable Nonprofits." Nonprofit and Voluntary Sector Quarterly 38:237-69.

Panel on the Nonprofit Sector. 2005. Strengthening Transparency, Governance, and Accountability of Charitable Organizations: A Final Report to Congress and the Nonprofit Sector. Washington, DC: Independent Sector. Accessed August 19, 2015. https://www. independentsector.org/uploads/Accountability_Documents/Panel_Final_Report.pdf.

Panel on the Nonprofit Sector. 2006. Strengthening Transparency, Governance, and Accountability of Charitable Organizations: A Supplement to the Final Report to Congress and the Nonprofit Sector. Washington, DC: Independent Sector. Accessed August 19, 2015. https://www.independentsector.org/uploads/Accountability_Documents/Panel_ Supplement_Final.pdf.

Panel on the Nonprofit Sector. 2007. Principles for Good Governance and Ethical Practice: A Guide for Charities and Foundations. Washington, DC: Independent Sector. Accessed August 26, 2015. http://www.hewlett.org/uploads/files/Principles_Guide.pdf.

Perry, S. 2012. "Barack Obama and the Nonprofit World." Chronicle of Philanthropy. Accessed September 4, 2012. https://philanthropy.com/article/Barack-ObamatheNonprofit/156157. 
Perry, S. 2015. "What the Poll Says: On Trust, Money, and Programs." Chronicle of Philanthropy (October 2015): 10-14.

Proscio, T. 2005. “Advocacy Funding: The Philanthropy of Changing Minds.” GrantCraft. http://www.grantcraft.org/assets/content/resources/advocacy_funding.pdf.

Roeger, K. L., A. S. Blackwood, and S. L. Pettijohn. 2012. The Nonprofit Almanac 2012. Washington, DC: Urban Institute Press.

Sabeti, H. 2011. "The For-Benefit Enterprise." Harvard Business Review (November 2011). https://hbr.org/2011/11/the-for-benefit-enterprise.

Salamon, L. M., S. Wojciech Sokolowski, and Associates. 2004. Global Civil Society: Dimensions of the Nonprofit Sector, Volume Two. Bloomfield, CT: Kumarian Press.

Senate Finance Committee. 2004. "Staff Discussion Draft." Accessed August 19, 2015. http:// www.finance.senate.gov/imo/media/doc/062204stfdis.pdf.

Stehle, V. 2009. "An Important Vote to Protect Charity Lobbying Rights.” Chronicle of Philanthropy. Accessed April 9, 2009. https://philanthropy.com/article/An-ImportantVote-to-Protect/175019.

Stiffman, E. 2015. “Group Works to Mobilize Millions of Nonprofit Workers to Vote." Chronicle of Philanthropy. Accessed July 24, 2015. https://philanthropy.com/article/Group-Works-toMobilize/231909.

Tocqueville, A. de. 1969. Democracy in America. Translated by Mayer, J. P.. Garden City, NY: Anchor Books, Doubleday \& Company.

Young, D. 2010. "Nonprofits and Public Policy in the United States: The Evolution of Accountability." In Policy Initiatives towards the Third Sector in International Perspective, edited by B. Gidron and M. Bar, 45-66. New York: Springer.

Young, D. R., L. M. Salamon, and M. C. Grinsfelder. 2012. "Commercialization, Social Ventures, and for-Profit Competition." In The State of Nonprofit America, 2nd ed., edited by L. M. Salamon, 521-48. Washington, DC: Brookings Institution Press. 